\title{
Editorial Welcome to Secular Studies
}

On behalf of the distinguished Editorial Board, we welcome readers to the inaugural issue of Secular Studies, the journal devoted to the theoretical, interdisciplinary, and international study of the secular, secularity, secularization, alternatives to religion, and secularism. The new field of secular studies has emerged at the intersections of psychological and sociological research, historical and cultural perspectives on secular trends, global studies of religion and nonreligion in society and politics, and dialogues between faith and reason. Many disciplines are becoming involved with these interrelated explorations and debates.

Secular Studies is an engaging and provocative arena for the humanities, intellectual history, philosophy, religious studies, anthropology, social and political theory, and behavioral and cognitive sciences. The journal is hospitable to new empirical findings, along with interpretations of their significance and conversations among scholars about broader implications. The members of the Editorial Board-listed in this journal and at brill.comexemplify how we invite many disciplines to participate in the journal.

Secular Studies publishes original research on secularity, both historical and contemporary, and secular issues and agendas from multi-disciplinary and international perspectives. Historical, literary, cultural, political, sociological, psychological, and philosophical studies of secular thought and living are sought, along with research on irreligion, atheism, agnosticism, humanism, and naturalism. Also welcome are comparative, intersectional, and cross-cultural studies of secularity and secular people, investigations into types of secularism and patterns to secularization, and explorations of church-state relations around the world.

In additional to research articles and book reviews, the journal welcomes responses to articles and proposals for special sections, such as Target Articles with peer commentaries; Author Meets Critics; Book Discussions; and groups of papers having a common theme. Contact the Editor for suggestions and proposals.

John R. Shook 